\title{
Site factors are more important than management for indicator species in semi-natural grasslands in southern Sweden
}

\author{
Per Milberg (1) - Karl-Olof Bergman • Anders Glimskär • Sigrid Nilsson • \\ Malin Tälle
}

Received: 21 July 2019/Accepted: 12 May 2020/Published online: 25 May 2020

(C) The Author(s) 2020

\begin{abstract}
Management of semi-natural grasslands is essential to retain the characteristic diversity of flora and fauna found in these habitats. To maintain, restore or recreate favourable conditions for grassland species, knowledge regarding how they occur in relation to grazing intensity and soil nutrient availability is crucial. We focused on grassland plant species, i.e., species selected to indicate high natural values in semi-natural grasslands. Environmental monitoring data collected at 366 grassland sites in southern Sweden between 2006 and 2010 were used to relate the occurrence of indicator species to factors describing geographic location, local site conditions related to nutrients and moisture, and management. Site productivity, soil moisture and cover of trees and shrubs were the main structuring factors, while other factors related to management had a lesser effect (grass sward height, amount of litter, type of grazer). Not surprisingly, these patterns were also reflected in species-wise analyses of the 25 most commonly occurring indicator species, with almost all species
\end{abstract}

Communicated by Sumanta Bagchi.

P. Milberg $(\bowtie) \cdot$ K.-O. Bergman · S. Nilsson · M. Tälle IFM Biology, Conservation Ecology Group, Linköping University, 58183 Linköping, Sweden

e-mail: per.milberg@liu.se

A. Glimskär

Department of Ecology, SLU, Box 7044, 75007 Uppsala, Sweden negatively related to site productivity and most also to soil moisture. Furthermore, many species were negatively affected by increasing sward height and litter. In contrast, species-wise responses varied among species in relation to increasing cover of trees and shrubs. In comparison to cattle grazing, sheep grazing was detrimental to six species and beneficial to none, while horse grazing was detrimental to no species and beneficial to four species. When evaluating species traits, taller plant species were favoured when site productivity, grass sward height and the amount of grass litter were high. There were no strong patterns related to the flowering time, leaf arrangement, or nutrient and light requirements of species. These results highlight the importance of nutrient-poor and dry sites, e.g., when selecting sites for conservation, and the importance of the type of management executed.

Keywords Grassland · Plants - Indicator species · Nutrients $\cdot$ Soil moisture $\cdot$ Grazing $\cdot$ Sweden

\section{Introduction}

A history of traditional agricultural management in the form of grazing and mowing formed species-rich semi-natural grasslands in many parts of Europe from the Neolithic Age onwards (e.g., Eriksson et al. 2002; Lindborg et al. 2006; Poschlod et al. 2009). Changes in 
agricultural practices over the last 150 years have greatly reduced the area of semi-natural grasslands and this area might be expected to decrease further in Sweden and elsewhere (Nordberg 2013). Many species found in these grasslands are adapted to nutrient-poor conditions with high light availability (Wahlman and Milberg 2002; Schrautzer and Jensen 2004; Köhler et al. 2005; Schreiber et al. 2009; Wallin and Svensson 2012; Milberg et al. 2017). Continued management is essential to preserve species-rich grasslands by preventing overgrowth of woody plants, and maintaining low-grown vegetation as well as edaphic conditions (Lennartsson 2000; Wahlman and Milberg 2002; Pykälä 2003; Svensson and Carlsson 2005; Klimek et al. 2007; Wallin and Svensson 2012; Komac et al. 2014; Tälle et al. 2018).

From the point of view of long-term biodiversity goals, it is important to select grasslands for conservation management that are most promising. Additionally, it is important to select the best management strategy to achieve biodiversity goals, e.g. the type of management (grazing, mowing, spring-burning; type of grazer), intensity of management (stocking density; mowing frequency), and timing of management (e.g., Milberg et al. 2017, 2018; Tälle et al. 2014, 2015, 2016, 2018).

Several studies have shown that plant species richness is highest in grasslands under more intense management (Pykälä 2004; Pöyry et al. 2006; Komac et al. 2014; Schrautzer et al. 2016), and it is generally thought that intense grazing reduces competition among plant species, thereby maintaining high species richness (e.g., Dorrough et al. 2007). Few studies have examined how plant species respond to a gradient in grazing intensity, but those that exist indicate that different types of species or plant traits are favoured by different grazing intensities (Deák et al. 2017; Tóth et al. 2018; Herrero-Jáuregui and Oesterheld 2018). The type of grazing animal has a less clear influence on conservation outcomes, at least if one adjusts for grazing intensity (Stewart and Pullin 2008). In general, however, sites grazed by sheep seem less valuable for biodiversity conservation than those grazed by cattle (Tälle et al. 2016; Tóth et al. 2018).

Pastures with shrubs and trees (Eriksson and Cousins 2014; Plieninger et al. 2015) are subject to an additional management issue. On the one hand, shrubs increase the heterogeneity and diversity (Dover et al. 1997; Söderström et al. 2001; Bergman et al.
2004; Pihlgren and Lennartsson 2008; Gazol et al. 2012). On the other hand, too much cover of woody plants shade out many typical grassland species (Einarsson and Milberg 1999). Currently, there is a paucity of information regarding shrub and tree management in wooded pastures.

Although the general patterns outlined above are established, there is a lack of studies on these management-related issues that can provide clear guidelines for management. An important reason is that experiments on grazing intensity, grazing animal type, and amounts of trees and shrubs are difficult to perform, and meaningful conservation outcomes emerge only after several years. Furthermore, the results are seldom transferable, as they need to be replicated over many sites, since factors such as site productivity, site history and other local conditions may play a crucial role (e.g., Milchunas et al. 1988; Milberg et al. 2017; Herrero-Jáuregui and Oesterheld 2018). An alternative to experiments is to use observational data from many different sites. Although lacking in detail, such studies may still reveal the relative importance of factors involved in creating biodiversity patterns under the prevailing types of management (e.g., Bergstedt and Milberg 2001; Pöyry et al. 2006; Milberg et al. 2016). In the present study, we used observational data stemming from a Swedish national monitoring programme involving speciesrich grasslands. We considered how plant speciesselected as indicators of species-rich grassland-occur in relation to inherent grassland site conditions: (1a) productivity using the Ellenberg $\mathrm{N}$ index (ENI) as a proxy and (1b) soil moisture using the Ellenberg $M$ index (EMI) as a proxy. An Ellenberg indicator value represents the simple ordinal classification of plants according to the position of their realized ecological niche along an environmental gradient (Ellenberg 1991). These values are widely used in ecology for a semi-quantitative description of species ecological requirements. In addition, we considered management-related factors: (2a) shading by shrubs and trees using their cover as a proxy; grazing intensity, using (2b) grass sward height and (2c) the amount of grass litter as negative proxies for grazing intensity; and the grazer types (2d) sheep and (2e) horses (compared to cattle). More specifically, we were interested in the relative importance of inherent site factors - those that cannot easily be manipulated by management-and management-related factors in regard to both species 
composition and species-wise responses. In addition, we examined such effects according to five attributes of species (plant height, leaf distribution along stem, flowering time, Ellenberg L (light) and Ellenberg $\mathrm{N}$ (Nutrients)), as plant traits may be used to explain and generalize a larger set of species groups. For example, plant height has repeatedly been shown to be related to the risk of being damaged by grazing (Díaz et al. 2007; Fujita and Koda 2015; Evju et al. 2009).

\section{Methods}

Monitoring program for valuable grasslands

This study was based on data collected within the environmental monitoring programme for valuable grasslands that was launched in 2006 and financed by the Swedish Board of Agriculture. The design and methods for this monitoring programme were coordinated with the National Inventory of Landscapes in Sweden (NILS), which is part of the national environmental monitoring programme financed by the Swedish Environmental Protection Agency (Ståhl et al. 2011). The overall sample that is the basis for the design of both the NILS and the grassland monitoring programme consists of a total of 631 landscape squares with an area of $25 \mathrm{~km}^{2}$. These landscape squares are systematically distributed across all of Sweden and thereby cover all types of landscapes, including agricultural land, wetlands, alpine environments, forests and urban areas. Within each landscape square, parts of the area are inventoried by trained staff every fifth year (Sjödin 2015). The inventories in the grassland monitoring programme are performed in one or more species-rich grassland sites within the $25 \mathrm{~km}^{2}$ landscape squares. Initially, the grassland sites had been randomly selected from the database of valuable grasslands ("Ängs- och betesmarksinventeringen", ÄoB) maintained by the Swedish Board of Agriculture in 2002-2004 (Persson 2005a, b; Öster et al. 2008).

\section{Sampling}

The sampling of plants was performed in plots distributed in a systematic pattern within each grassland site. The total number of plots in each grassland site varied between one and ten depending on the area of the grassland site. The coordinates for the plot centres were derived by forming a grid with a random starting point (Fig. 1a). Each plot consists of a circular area with a radius of $10 \mathrm{~m}$. However, to better represent the tree and shrub layer and its possible impact on the ground vegetation, trees were recorded over a larger area at each plot centre (radius of $20 \mathrm{~m}$ ). Within each plot, nine circular subplots $(0.28 \mathrm{~m}$ diameter, i.e., $0.25 \mathrm{~m}^{2}$ ) were used for sampling the vascular plant species in the field layer (Fig. 1b). Species favoured by grassland management (hereafter "grassland species") $(\mathrm{N}=70)$ were recorded in all nine subplots. The list of grassland species was based on the selection of indicator species within the original ÄoB grassland survey (Persson 2005a, b; Öster et al. 2008) and supplemented with some additional species to broaden the ecological range.

The original list of indicator species was selected by consensus decisions of a group of grassland experts and experienced staff at the Swedish Board of Agriculture and country administrative boards, and the occurrence of these species was one important criterion for the identification of the valuable sites in the original grassland survey (Persson 2005a, b). However, from earlier studies, it was concluded that the list to some extent was biased towards species from dry-mesic, open conditions in southern Sweden (Grandin et al. 2013). Therefore, 12 species were added to the list of indicator species in the general grassland field variable list, in addition to the original 60 indicator species (Table 2 in Appendix). However, a few species have a markedly northern boreal-toalpine distribution (Aconitum lycoctonum, Bartsia alpina; Table 2 in Appendix), which means that they are not relevant for the current analyses that included only southern Sweden.

In addition to grassland species, species from a longer list of 189 vascular plant species were recorded in the three subplots closest to the centre of each plot (Fig. 1b, Sjödin 2015), which were then used for a more general vegetation description (productivity and moisture indices, see below). A number of common mosses and lichen species were also sampled in these three subplots, but they were not included in the current analyses, since we considered them to be less useful as indicators of management effects.

Our primary focus in the present analyses was the more intensively sampled grassland species. We 

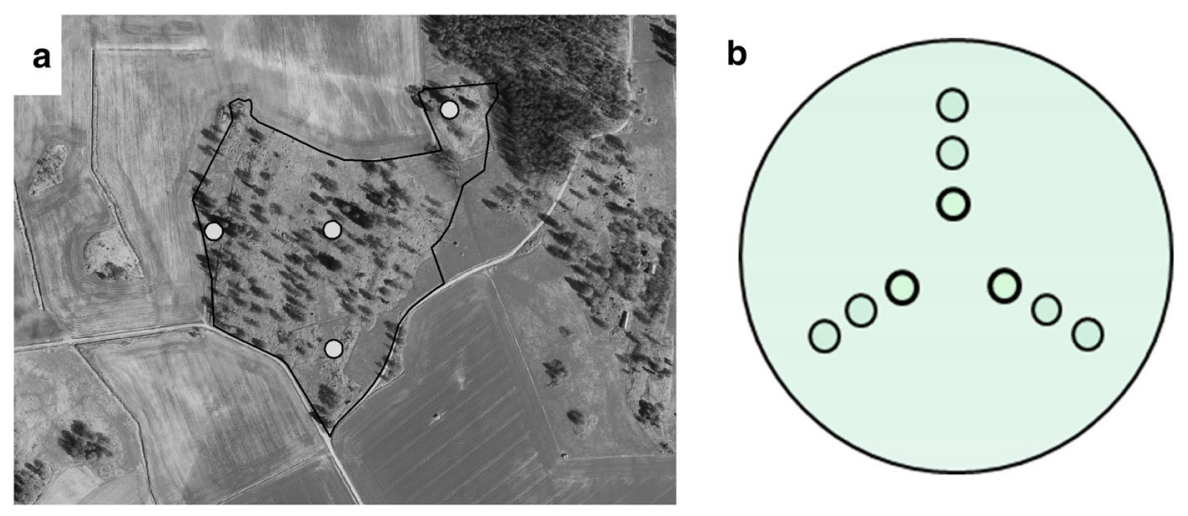

Fig. 1 Schematic description of the plot arrangement in the grassland monitoring programme. a Example of the distribution of plots at a grassland site. The coordinates were derived by forming a checked pattern with a random starting point.

subjected such data to multivariate analyses and performed species-wise analyses of the 25 most frequently occurring species or species groups (present in $\geq 23$ subplots). These species all occurred over the full study area.

Within each plot, vegetation height was recorded as the estimated percent cover of grass sward vegetation within each of three height intervals: $<5 \mathrm{~cm}, 5-15 \mathrm{~cm}$ and $>15 \mathrm{~cm}$. To achieve a plot-wise number, the vegetation height categories were transformed from a range to a single value. The category " $<5 \mathrm{~cm}$ " was transformed to $2.5 \mathrm{~cm}$, " $5-15 \mathrm{~cm}$ " was transformed to $10 \mathrm{~cm}$, and " $>15 \mathrm{~cm}$ " was transformed to $25 \mathrm{~cm}$. The percentage for each category was multiplied by the value of that category, and the three values were then summarized to obtain a mean value of grass sward vegetation height for each plot. The estimation of cover for each height interval was calibrated with the help of a rising-plate metre originally designed for estimating dry matter yield in pastures (Earle and McGowan 1979; Laca et al. 1989), where a plate of the size $30 \times 30 \mathrm{~cm}$ and weight of $430 \mathrm{~g}$ is carefully lowered to rest on top of the grassland field layer vegetation. The cover for each height interval corresponds to the proportion of measurements with such a rising-plate metre that fall into each height interval. Additionally, the proportion of the plot area that lacks grassland vegetation is estimated so that the summary of cover values adds up to $100 \%$. The amount of graminoid litter is based on the visual estimation of the vertical cover of dead leaves of grasses, sedges and rushes over the entire area of the plot. b Outline of a sampling unit. The indicator plant species were recorded in nine subplots, and a longer species list of 170 species was used only for the inner three subplots, which in the current study were used only for the ENI and EMI calculations

From data collected in the field and based on the longer list of 189 vascular plant species recorded only within the central three subplots (Fig. 1b), a site productivity index (ENI, a number between 1 and 9) was calculated based on the occurrence of the species and their Ellenberg $\mathrm{N}$ values (larger numbers indicating a preference for $\mathrm{N}$-rich soils). For each plot, the weighted arithmetic average Ellenberg $\mathrm{N}$ value (for all species present from the longer species list) was calculated for each plot based on those species present, where the number of subplots per plot (1-3) was used as the abundance weight. The calculation was performed with the method described by Diekmann (2003), where $r_{i j}$ is the abundance value for species $i$ in plot $j$, and $x_{i}$ is the indicator value of species $i$.

Weightedaverage $=\sum_{i=1}^{n}\left(r_{i j} * x_{i}\right) / \sum_{i=1}^{n} r_{i j}$

Additionally, a site moisture index (EMI, a number between 1 and 12) was calculated based on the occurrence of the species and their Ellenberg M values (larger numbers indicating a preference for high soil moisture) in the same way as for ENI.

\section{Criteria for grassland selection}

As the species composition, management, and density of grasslands differ between the northern and southern parts of Sweden, this study focused on data from grassland sites in the southern part only. Data from the islands of Gotland and Öland, which have deviating geology and flora (e.g., Rosén 1982), were also excluded (Fig. 2). Data collected between 2006 and 


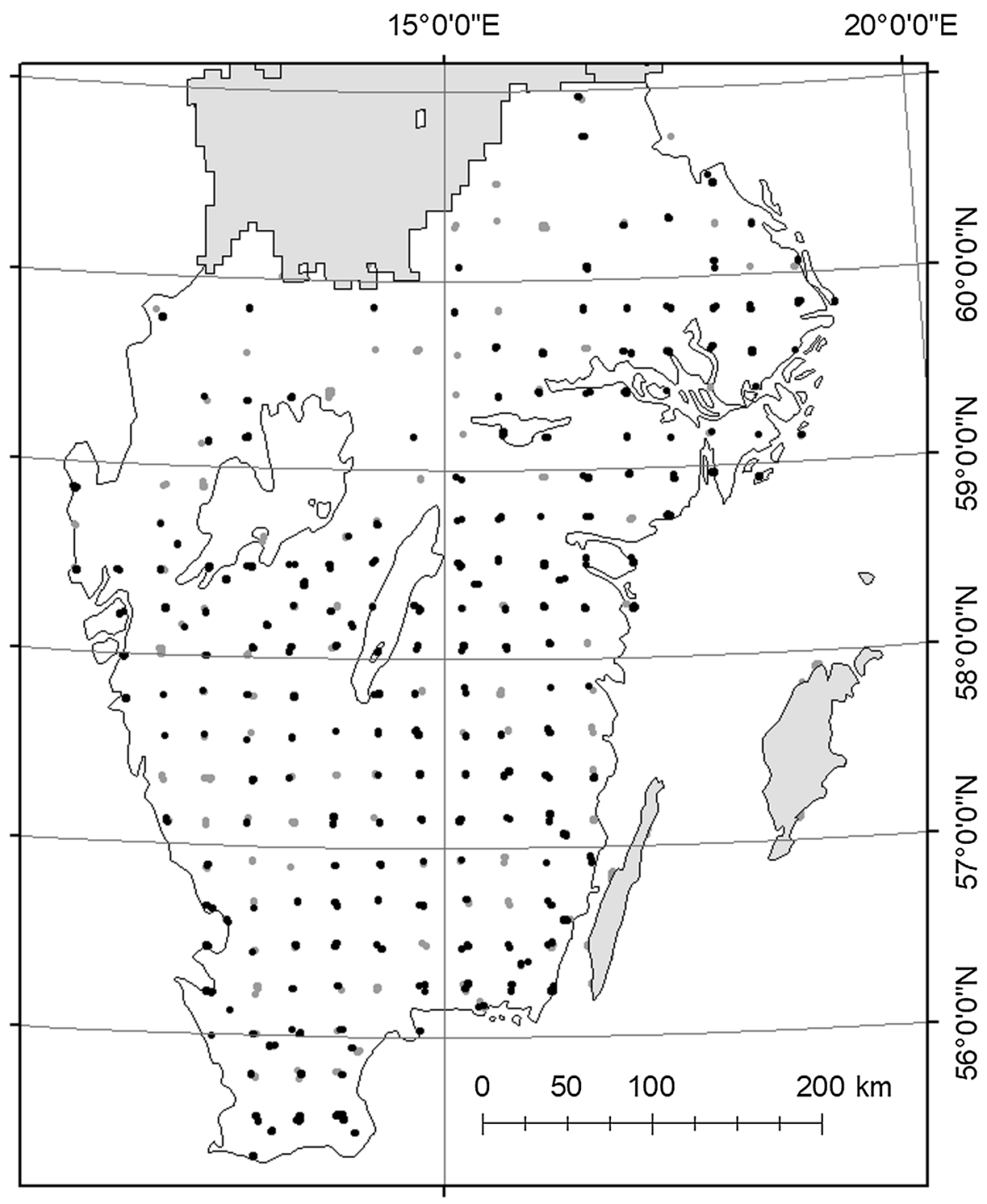

Fig. 2 The distribution of the grassland sites used (black dots) and those excluded (grey dots). All sites were part of a monitoring program that covers all of Sweden; grey areas were excluded (see text for sampling details and exclusion criteria)

2010 were used, thereby avoiding inclusion of the same site more than once. Mowing affects sward height abruptly, and mowed sites were therefore excluded, as were the grassland sites with land use classified as "forest", "grazed ley" and "grazed fertilized". In addition, pastures grazed by deer or "unknown" animals or where the record was "NA" were also excluded, leaving cattle, horses and sheep. Finally, plots that did not have the target of 9 subplots were excluded (e.g., plots that ended up partly outside a fence or on a rock). These criteria led to a total of 919 plots. The number of plots per grassland site varied between 1 and 6 , with an average of 2.5; the average proportion of the site covered was $0.015 \%$ (SD 0.018). The average size of the 366 grassland sites was approximately 4 hectares.

Plant species classification

The grassland species included within the field protocol (Sjödin 2015) were classified according to ecological traits to facilitate group-wise analyses. The traits considered were plant height, leaf distribution along the stem, flowering time, nutrient availability 
preference (Ellenberg $\mathrm{N}$ ) and light preference (Ellenberg $\mathrm{L}$, with larger numbers indicating a preference for sun-lit conditions). Data on plant height and leaf distribution along the stem were extracted from the LEDA Traitbase (Kleyer et al. 2008), while Ellenberg N and Ellenberg $\mathrm{L}$ values were extracted from Ellenberg et al. (1992). In cases where more than one original source existed, we used the average (plant height) or selected the most frequent type. Due to the low number of species in some classes, Ellenberg N4 and N5 were merged, as were Ellenberg L4-L6. Data on flowering time were derived from Krok and Almquist (2012), with early flowering being defined as occurring when the main flowering time of a species was earlier than midsummer and late flowering being defined as occurring when the main flowering time was during mid-summer or later.

Statistical analyses

\section{Multivariate analyses}

We conducted multivariate analyses of the 70 indicator species to determine the relative importance of our explanatory variables (Table 1). Because observational data are potentially subject to spatial autocorrelation, we used principal coordinate analysis of neighbour matrices (PCNM, Dray et al. 2006). In this way, we could compare the explanatory power of the environmental variables when taking the spatial origin of the data into account as well as when ignoring it. As PCNM cannot handle samples that lack species, 193 of the 919 plots were excluded in these analyses.

\section{Species-wise analyses}

Data from 25 plant species (or species groups) were subjected to individual, generalized linear models (binomial distribution and logit link) relating the presence of grassland species to the explanatory variables, using the software Statistica 13. The data for most species did not allow the construction of a model with all explanatory variables simultaneously, so to allow comparability, we constructed one model per explanatory variable. Two spatial variables were included to adjust for possible spatial gradients. The partial regression coefficients (with $\mathrm{CI}_{95 \%}$ ) resulting from the species-wise analyses were then used in

Table 1 Average, SD, min and max of each variable used in the analyses. Values for grazer type represent the number of plots grazed per type. Correlation coefficients are shown at the bottom of the table

\begin{tabular}{lllll}
\hline & Average & SD & Min & Max \\
\hline $\begin{array}{l}\text { Explanatory variables } \\
\text { Number of grassland spp per } 0.25 \mathrm{~m}^{2} \text { subplot }\end{array}$ & 1.11 & 1.37 & 0.00 & 12.00 \\
$\quad$ North coordinate (WGS84) & & & 55.32 & 60.91 \\
East coordinate & & & 11.56 & 19.25 \\
Ellenberg nutrient index (ENI) & 4.22 & 1.19 & 1.00 & 8.33 \\
Ellenberg moisture index (EMI) & 5.24 & 1.13 & 2.00 & 10.00 \\
Square root of cover of trees and shrubs (\%) & 4.09 & 3.11 & 0.00 & 12.85 \\
Square root of grass sward height (cm) & 3.02 & 0.94 & 1.58 & 5.00 \\
Square root of litter amount (\% cover) & 5.02 & 2.47 & 0.00 & 9.95 \\
Cattle & 699 & & & \\
Horses & 122 & & & \\
Sheep & 104 & & & \\
Correlation matrix & & & & \\
& B & C & 0.157 & 0.073 \\
A. ENI & 0.252 & -0.105 & 0.348 & 0.231 \\
B. EMI & & -0.075 & 0.061 & -0.259 \\
C. Square-root of cover of trees \& shrubs & & & & 0.313 \\
D. Square-root of grass sward height & & & \\
E. Square-root of litter amount
\end{tabular}

${ }^{a}$ Numbers used in GLZ were coordinates according SWEREF99, converted from $\mathrm{m}$ to $\mathrm{km}$ 
meta-analyses to evaluate group-wise responses to differences in grass sward height (Comprehensive Meta-Analysis 2.2; www.meta-analysis.com).

\section{Results}

Multivariate analyses

According to the multivariate analyses, the explanatory variables evaluated explained $4.4 \%$ of the variation in the compositional data (adjusted explained variation), which was reduced to $4.2 \%$ when accounting for the spatial autocorrelation in the data. Overall, there were only small differences in the biplots with and without accounting for spatial autocorrelation (Fig. 3).

The most decisive factor affecting species composition was soil moisture (Fig. 3, long arrow almost parallel to the first ordination axis), with soil nutrients and cover of trees and shrubs also being important (long arrows aligning with the second axis). In contrast, the other management-related variables were less important, as these had short arrows (grass litter,

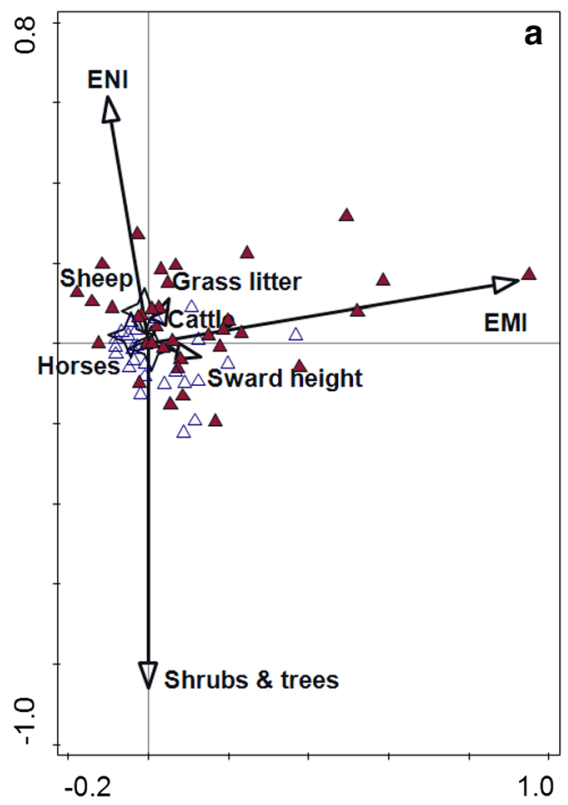

Fig. 3 Ordination graphs from the PCNM of 70 indicator species and a number of explanatory variables. a Shows analysis with edaphic and management related variables (eigenvalues of axes 1 and 2 were 0.36 and 0.17 , respectively). b Shows the corresponding analysis after adjusting for spatial correlation sward height) or were located close to the origin (grazing animals; Fig. 3).

Species-wise analyses of grassland plant species

When analysing species-wise effects, the two variables describing site conditions had the strongest impact, with 22 and 19 of the 25 species analysed showing a significantly negative relationship with the ENI and EMI, respectively (Fig. 4a,b). One species (Carex panicea) showed a positive relationship with an increase in the EMI (Fig. 4b). In contrast, management-related variables had a weaker impact. The cover of trees and shrubs significantly affected seven species negatively (and four species positively, Fig. 4c), while grass sward height negatively impacted 13 species (and one species positively, Primula veris; Fig. 4d). The amount of litter-a proxy for the previous season's grazing intensity-negatively affected four species (Fig. 4e). Compared with cattle grazing, sheep grazing affected six species negatively, while horse grazing positively affected three species (Fig. 4f, g).

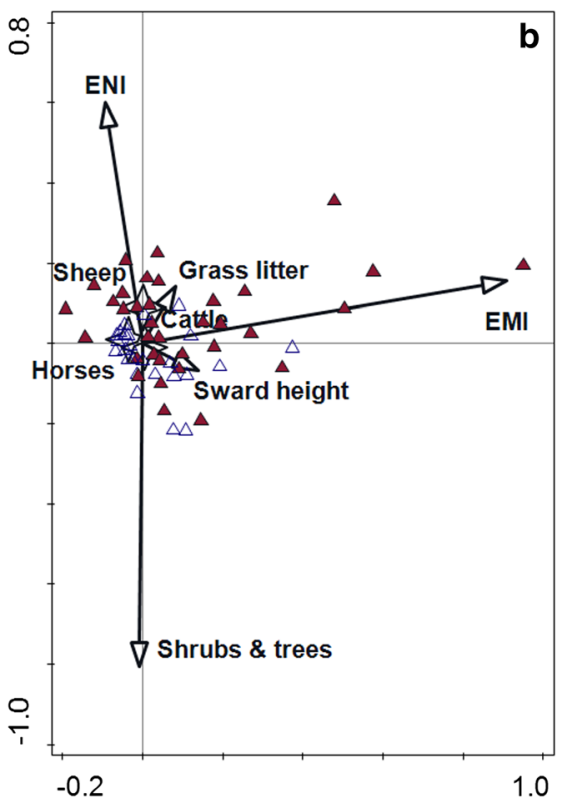

(eigenvalues 0.35 and 0.16 ). Unfilled stars represent the centroid of the three types of grazing animals, empty triangles represent the 25 species subjected to species-wise analyses, and black triangles represent the other species (which were deemed too rare for species-wise analysis) 

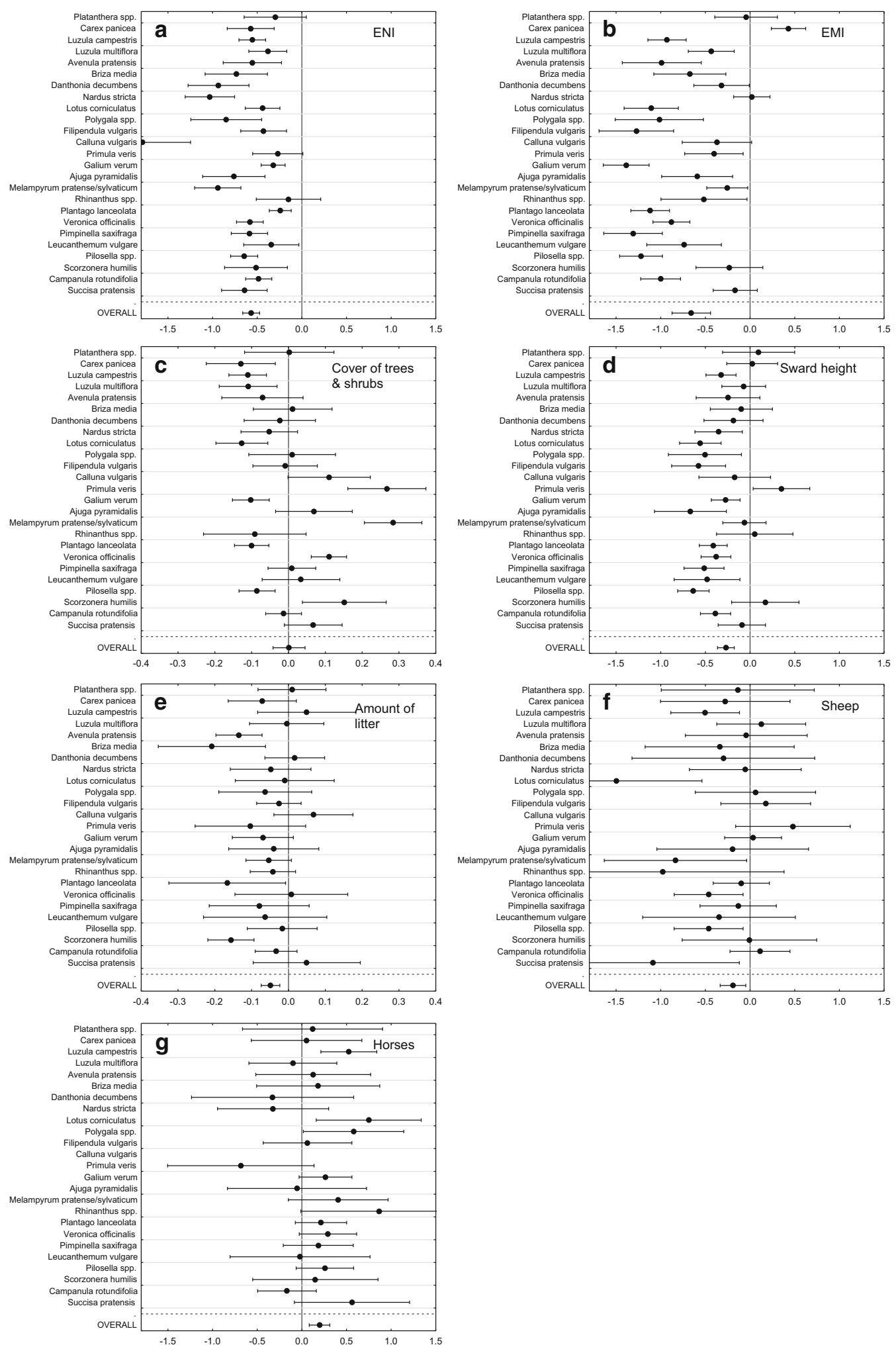

Regression coefficient 
4Fig. 4 Species-wise responses (with $\mathrm{CI}_{95 \%}$ ) for grassland species in binomial regressions with, a the Ellenberg $\mathrm{N}$ index i.e. nutrient availability (ENI), b Ellenberg $M$ index, i.e. soil moisture (EMI), c cover of trees and shrubs, $\mathbf{d}$ grass sward height, $\mathbf{e}$ amount of litter, $\mathbf{f}$ sheep as grazing animal compared with cattle, and $\mathbf{g}$ horses as grazing animal compared with cattle. A negative value indicates a decreasing probability of occurrence as the explanatory factor increases

Trait-wise analyses

All trait groups showed general preferences to drier soils, nutrient poor soils, lower grass sward height and low amount of litter except for plant height, which was favoured when site productivity, grass sward height and the amount of grass litter were high (Fig. 5). The trait groups showed a general negative response to grazing by sheep and a positive to horse grazing. There was, however, a tendency for two attributes-flowering time and leaf distribution-to be differently affected by the type of grazing animal. Species with late flowering as well as species with leaves throughout the stem were negatively and positively affected by sheep and horse grazing, respectively. Neither the Ellenberg $\mathrm{L}$ nor the Ellenberg $\mathrm{N}$ values of the grassland species showed clear interpretable patterns (Fig. 5), possibly with the exception that species that prefer maximum sunlight are more negatively affected by the ENI than other species (Fig. 5a).

\section{Discussion}

In the present study, the most important variables were related to site conditions. This corroborates previous reports based on observational data (Gilhaus et al. 2017) and studies focusing on the effects of site productivity and soil moisture on grassland species in general and the occurrence of individual grassland species (e.g., Moeslund et al. 2013; Tälle et al. 2015; Humbert et al. 2016). These results can be seen in the light of the evolution of the species now part of plant communities in semi-natural grasslands. Grassland vegetation has existed in Europe at least the last 1.8 million years and at the end of each interglacial the amount of grasslands on infertile soils has increased (Pärtel et al. 2005). So the selection pressure over millions of years has been towards surviving in nutrient poor soils (in addition to enduring grazing).
It was not until inorganic fertilisers were introduced that important selection pressures abruptly changed, which is probably one of the reasons for our plot-wise site productivity variable (ENI) was so important. The large impact of soil moisture may also be indirectly related to this, as dry conditions can reduce plantavailable nutrients (e.g. Gahoonia et al. 1994; Misra and Tyler 2000). Cover of trees and shrubs also had a substantial effect on composition, suggesting that the adaptation to open grass-dominated environments with regular grazing disturbance rarely goes hand in hand with the ability to prosper under shade (da Silveira et al. 2015).

It is somewhat questionable to compare the relative importance of one type of variable that is an inherent and resilient feature of the site (ENI, EMI) with one that depends both on weather and management decisions on stocking density and grazing period (grass sward height, amount of litter). Nevertheless, the broad patterns suggest that site conditions have a much larger impact on the occurrence of most grassland species than management-related factors, which is in line with the finding by Gilhaus et al. (2017) that site conditions and the regional species pool play a more important role than the type of management. It is possible that our species might be more well-adapted to nutrient-poor site conditions than to specific types of management (cf. Oelmann et al. 2009; Gilhaus et al. 2015). The grassland sites included in the present study were all species-rich grasslands under management in the current, or at least preceding, year and they were distributed over a large region across southern Sweden. With the expected variation in stocking density and the starting date of grazing as well as weather and site productivity, a substantial degree of variation in the managementrelated variables grass sward height and amount of grass litter was to be expected among sites. Furthermore, it could be expected that part of this variation is attributed to site productivity. However, the ENI was only weakly correlated with grass sward height and the amount of litter. Therefore, for the data used, it seems that grazing intensity and site productivity were unrelated. Unfortunately, there are no data on stocking density from these sites for a more direct analysis of such effects; therefore, we used grass sward height and the amount of litter as indirect indicators of management intensity. In addition, to the best of our knowledge, there is no established method to quantify 

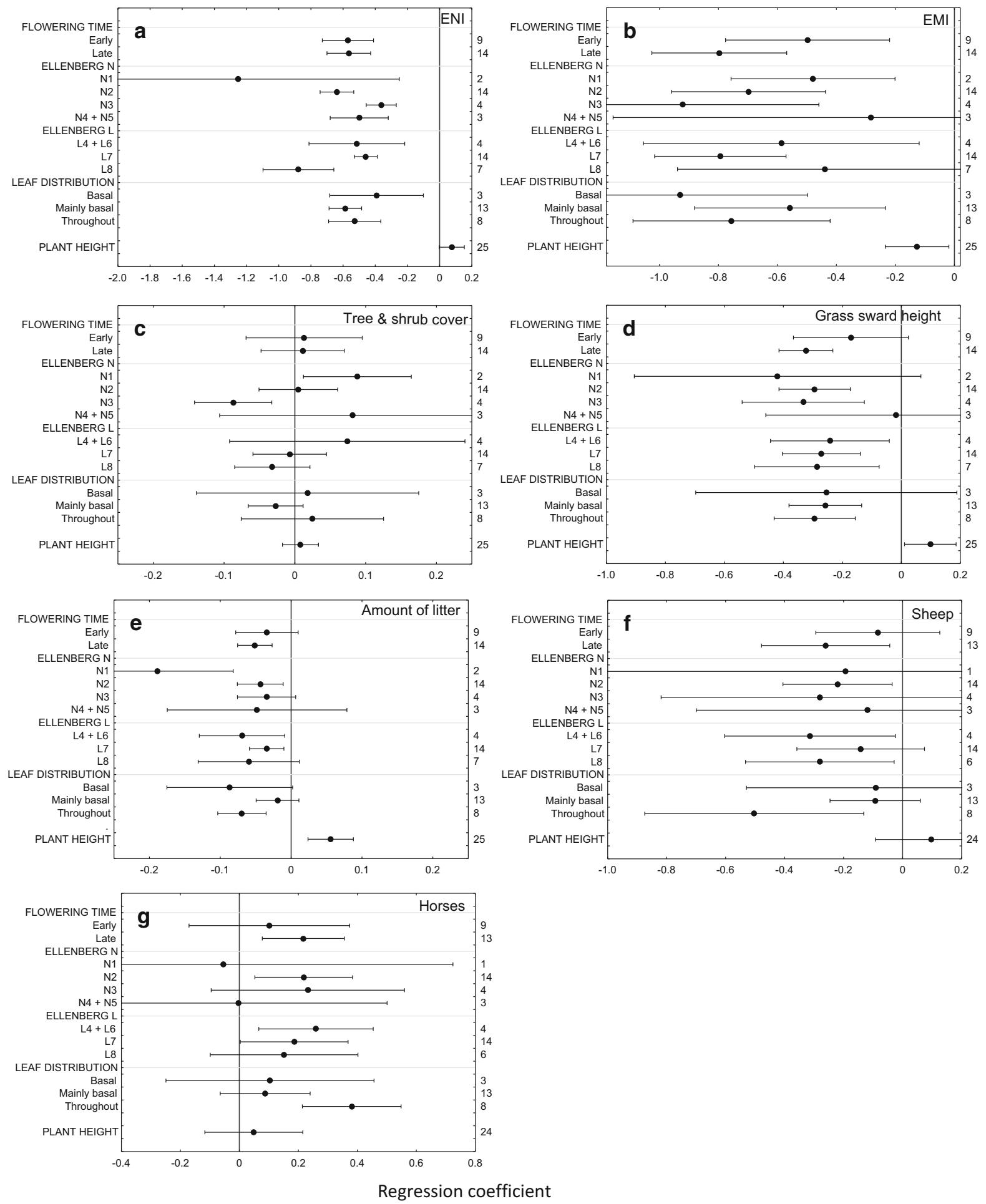
४Fig. 5 Forest plots showing grassland species grouped according to different species traits. The $\mathrm{X}$-axis shows the average values of partial regression coefficients (with $\mathrm{CI}_{95 \%}$ ) using seven different explanatory variables. a ENI, Ellenberg $\mathrm{N}$ index, i.e. nutrient availability at sites. b EMI, Ellenberg M index, i.e. soil moisture of sites. $\mathbf{c}$ Tree and shrub cover. d Grass sward height. e Amount of litter. f Sheep as grazing animals compared with cattle. g Horses as grazing animals compared with cattle. Ellenberg N1 is species with preference for the most nutrient poor soils; Ellenberg L8 is species with preference for full light conditions. Numbers to the right indicate the number of species in a group. The $\mathrm{X}$-axis shows the average values of partial regression coefficients

the effect of stocking density that can reliably take into account the large variation in sward productivity within and among sites of seminatural grasslands in Sweden (Pelve 2010). With this in mind, it is possible that grass sward height and amount of litter are not the best proxies for management. Thus, it is not surprising that in our study, management had less importance for grassland plant species than variables related to site conditions despite the many previous studies revealing the importance of management in experiments (e.g., Hansson and Fogelfors 2000; Wahlman and Milberg 2002; Schreiber et al. 2009).

While the results from species-wise analyses were complex, they suggest that management variables other than the cover of trees and shrubs could also play a role. Approximately half of the species were clearly affected by sward height (some positively so), while few species were affected by the amount of litter. The results also revealed that some species were more negatively affected by sheep than cattle grazing, while no species clearly benefited from sheep grazing. In contrast, horse grazing was detrimental to none of the species. Previous studies have reported the importance of light and shading for plant species (Einarsson and Milberg 1999), and other studies have found that the type of grazing animal and the amount of litter can be important. For example, there is evidence of the negative effects of sheep grazing (Tälle et al. 2016) and high amounts of litter (Kelemen et al. 2013; Loydi et al. 2013) on plant species.

The trait-based analyses only revealed a significant relationship between plant height and the explanatory variables evaluated (four of the seven). Plant height was positively affected by increasing site productivity (ENI) and-somewhat surprisingly-negatively affected by increasing soil moisture (EMI).
Corroborating previous experimental results (Milberg et al. 2017), plant species height was also positively related to attributes of relaxed management (grass sward height and amount of litter). One possible explanation for the negative correlation between plant height and increasing soil moisture may be related to the selection principles used for grassland species (cf. Grandin et al. 2013): most moist grasslands in Sweden are species-poor and dominated by common species, whereas the species of special conservation value -i.e. candidates for our "grassland species" - are likely to occur in nutrient-poor calcareous moist grasslands or marine seashore grasslands with long history of continuous management, both vegetation types being low-grown. For example, the only grassland species with a positive correlation with EMI was Carex panicea, which is also one of the more low-growing species mainly occurring in nutrient-poor calcareous grasslands.

When analysing the species' attributes, there was also a tendency for the effects of horse grazing to be positive (compared with cattle) for late-flowering species and species with leaves distributed throughout the stem, while they were negatively affected by sheep. This is partly in line with our current understanding of grazer plant preferences and grazing style. For example, small herbivores usually select higherquality foods, and, e.g., the. morphology of the mouthparts or digestive physiology may affect which plants and plant parts different animals prefer to eat. In general, sheep are more selective grazers than larger herbivores, such as cattle and horses, while horses generally have longer grazing times and can graze closer to the ground than cattle (Menard et al. 2002; Rook et al. 2004).

Why were there no clear, interpretable patterns among species when it comes to Ellenberg $\mathrm{N}$ and Ellenberg L? First of all, it is important to note that we used a selection of species (grassland indicators), and that this selection likely narrowed the range of available $\mathrm{N}$ and $\mathrm{L}$ values, making it more difficult to discern trends among species. Second, it is possible that these dimensions of their ecological niches were not important, at least not under the relatively short environmental gradients under scrutiny and the ecologically relatively homogeneous species involved in the analyses. Alternatively, Ellenberg values, being point estimates, might not describe the ecological niche well (Carroll et al. 2018). 
It is important to note that the species analysed were among 70 species considered to be grassland plants (grassland indicators, which are monitored with a more ambitious sampling effort) and do not represent a full vegetation survey. Nevertheless, we expected that the size of the dataset (366 sites, 919 plots and 70 taxa) would allow identification of species traits that could indicate the type of species associated with inherent site conditions (ENI, EMI) and management decisions (cover of trees and shrubs, grass sward height, amount of litter, type of grazing animal). However, the number of taxa that were recorded in sufficient numbers for meaningful analysis was modest ( 25 species or species groups), and some of the estimates were uncertain (large $\mathrm{CI}_{95 \%}$ ) due to low number of occurrences. Furthermore, the rarest species were not analysed because of no or few occurrences, hence a strong selection bias against the rarest species. So, if rarity is a consequence of management, then the rarest species might tell a different story but detecting this requires a design better suited for such species.

\section{Grassland management implications}

Using observational data from a monitoring program, as in this case, to draw conclusions regarding management and conservation priorities has obvious limitations. For example, there was a lack of sufficient data for rare species, and it was not possible to elaborate on mechanisms behind some factors (due to lack of detail, and lack in experimental design). Other limitations involved the selection of species monitored (only indicator species), and the edaphic limitations as grassland types with small areal extent risk being outliers, both in a statistical and an ecological sense. Examples are both alvar grasslands and rich fens. Regarding moist grassland, species-rich marine seashore meadows exist in data, but only rarely. Rather, the most common type of high-moisture grasslands in this study are on clayey soils or otherwise productive land in agriculturally dominated regions or at eutrophic or mesotrophic lake shores.

On the other hand, using large-scale data covering many different sites can reveal patterns that are difficult to study in time- and scale-limited experimental studies. Thus, in spite of some limitations, we argue that monitoring can provide data that can contribute to ecological understanding and to inform management decisions. In the present study, we highlight six aspects relevant for biodiversity conservation.

First, the clear association of many grassland plant species with sites that are low in nutrients and low moisture suggests that this information can be useful when identifying conservation priorities. For example, when selecting sites for restoration or for long-term commitment to management, less productive and/or dry sites are in most cases preferable. In addition, information on site productivity and soil moisture might also be important for managers, as more productive sites that harbour valuable plant species might be more sensitive to relaxed management, and therefore, to a larger extent requiring continuous management.

Second, it is reassuring that the managementrelated variables grass sward height and amount of litter seem to be less important for many grassland species than other variables, broadly suggesting that relaxed management over a season or two might not be detrimental (cf. Milberg et al. 2017; Tälle et al. 2018) for all but a few species (e.g., Ajuga pyramidalis, Filipendula vulgaris, Lotus corniculatus and Pilosella spp.). However, it should be borne in mind that other rare grassland species exist that are sensitive to high amount of litter, like Gentianella campestris (Lennartsson and Oostermeijer 2001), but such species were too rare to be included in the current analysis. It is also worth noting that the low explanatory power of vegetation height (and litter) could be a consequence of height tending to be low for fundamentally different reasons: when grazing intensity is high, when a site is dry or nutrient poor, and when a site occurs under deep shade. Adding to the variation is also the development during the growth season. Sward height had greater explanatory power than the amount of litter for individual species, so the former seems preferable for usage as a management indicator.

Third, cover by trees and shrubs had a negative impact on most species. Although hardly surprising given the well-established secondary succession towards forest that occurs when management ceases (Meiners et al. 2015; Milberg et al. 2017) and the 
effects of shading in grasslands (Einarsson and Milberg 1999), more research would be welcome to provide decision support for clearing strategies. Shade provided by trees and shrubs is also an administrative challenge of defining which grasslands are eligible for state and/or EU support for the preservation of biodiversity (Beaufoy et al. 2011; Blom 2012).

Fourth, this study confirmed the results of several previous reports (Öckinger et al. 2006; Scohier et al. 2013; Tälle et al. 2016; Tóth et al. 2018) concluding that sheep grazing is not the best option for conservation grazing at currently used stocking densities, as no species benefited from sheep grazing, and six species were more negatively affected by sheep than cattle grazing (Luzula campestris, Lotus corniculatus, Melampyrum spp., Veronica officinalis, Pilosella spp., Succisa pratensis). It remains to be investigated whether this detrimental effect can be ameliorated by adjusting the grazing regime, e.g., reducing stocking density, or through diversifying grazing intensities, either over time (e.g., rotational grazing) or space (e.g., enhancement of shrubs).

Fifth, our results suggest that horse grazing, under the prevailing grazing strategies in Sweden, should be considered to be an alternative to cattle grazing, as horse grazing had a more positive effect on Luzula campestris, Lotus corniculatus and Polygala spp. than cattle grazing and was detrimental to no species. In other studies, horses have not been preferred for use in conservation grazing (Dutch saltmarshes, van Klink et al. 2016; British grasslands; Rook et al. 2004), most likely due to their long grazing season and/or high stocking density creating a low, uniform sward.
Sixth, the results from this study might provide insight into identifying indicator species for resultoriented subsidies (Wittig et al. 2006; Bertke et al. 2008; Herzon et al. 2018), i.e., using those species identified as most sensitive to management decisions.

Acknowledgements Open access funding provided by Linköping University. We thank numerous fieldworkers for their devoted inventory efforts. The biodiversity sampling in grasslands was funded by the Swedish Board of Agriculture. We thank Åsa Ingegerd Eriksson, Erik Cronvall and Saskia Sandring at the Department of Forest Resource Management, Swedish University of Agricultural Sciences, for providing data and expertise.

Open Access This article is licensed under a Creative Commons Attribution 4.0 International License, which permits use, sharing, adaptation, distribution and reproduction in any medium or format, as long as you give appropriate credit to the original author(s) and the source, provide a link to the Creative Commons licence, and indicate if changes were made. The images or other third party material in this article are included in the article's Creative Commons licence, unless indicated otherwise in a credit line to the material. If material is not included in the article's Creative Commons licence and your intended use is not permitted by statutory regulation or exceeds the permitted use, you will need to obtain permission directly from the copyright holder. To view a copy of this licence, visit http://creativecommons.org/licenses/by/4.0/.

\section{Appendix}

See Table 2 in Appendix. 
Table 2 Indicator species used in the monitoring system, and their requency in the selected plots in southern Sweden

\begin{tabular}{|c|c|c|c|c|c|c|c|}
\hline $\begin{array}{l}\text { Species subjected to individual } \\
\text { analyses }\end{array}$ & & $\begin{array}{l}\text { Frequency } \\
\text { in plots } \\
(N=919)\end{array}$ & $\begin{array}{l}\text { Plant } \\
\text { height } \\
(\mathrm{m})\end{array}$ & $\begin{array}{l}\text { Ellenberg } \\
\text { (L) }\end{array}$ & $\begin{array}{l}\text { Ellenberg } \\
(\mathrm{N})\end{array}$ & $\begin{array}{l}\text { Flowering } \\
\text { time }\end{array}$ & $\begin{array}{l}\text { Leaf } \\
\text { arrangement }\end{array}$ \\
\hline Plantago lanceolata* & Plantaginaceae & 300 & 0.16 & 46 & Blank & Late & $\begin{array}{c}\text { Rosette/ } \\
\text { tufted }\end{array}$ \\
\hline Galium verum & Rubiaceae & 268 & 0.38 & 7 & 3 & Late & \\
\hline Pilosella spp.* & Asteraceae & 248 & 0.06 & 8 & 2 & Blank & $\begin{array}{c}\text { Rosette/ } \\
\text { tufted }\end{array}$ \\
\hline Luzula campestris* & Juncaceae & 243 & 0.27 & 7 & 2 & Early & Semi-rosette \\
\hline Veronica officinalis & Plantaginaceae & 241 & 0.13 & 46 & 45 & Late & \\
\hline Campanula rotundifolia* & Campanulaceae & 237 & 0.19 & 7 & 2 & Late & Semi-rosette \\
\hline Alchemilla spp.* & Rosaceae & 236 & & & & & \\
\hline Pimpinella saxifraga & Apiaceae & 123 & 0.41 & 7 & 2 & Late & Semi-rosette \\
\hline Lotus corniculatus & Fabaceae & 109 & 0.18 & 7 & 3 & Late & \\
\hline Melampyrum pratense/sylvaticum* & Orobanchaceae & 85 & 0.26 & 46 & 2 & Late & \\
\hline Nardus stricta & Poaceae & 81 & 0.12 & 8 & 2 & Early & Semi-rosette \\
\hline Succisa pratensis & Caprifoliaceae & 69 & 0.34 & 7 & 2 & Late & \\
\hline Filipendula vulgaris & Rosaceae & 62 & 0.32 & 7 & 2 & Late & Semi-rosette \\
\hline Carex panicea & Cyperaceae & 55 & 0.15 & 8 & 45 & Blank & Semi-rosette \\
\hline Danthonia decumbens & Poaceae & 52 & 0.10 & 8 & 2 & Late & Semi-rosette \\
\hline Primula veris/elatior & Primulaceae & 46 & 0.13 & 7 & 45 & Early & $\begin{array}{c}\text { Rosette/ } \\
\text { tufted }\end{array}$ \\
\hline Briza media & Poaceae & 38 & 0.16 & 8 & 2 & Late & semi-rosette \\
\hline Leucanthemum vulgare & Asteraceae & 38 & 0.36 & 7 & 3 & Late & \\
\hline Ajuga pyramidalis & Lamiaceae & 37 & 0.15 & 7 & 1 & Early & Semi-rosette \\
\hline Avenula pratensis & Poaceae & 37 & 0.65 & 7 & 2 & Early & Semi-rosette \\
\hline Calluna vulgaris* & Ericaceae & 31 & 0.48 & 8 & 1 & Late & \\
\hline Scorzonera humilis & Asteraceae & 29 & 0.25 & 7 & 2 & Early & Semi-rosette \\
\hline Platanthera spp. & Orchidaceae & 27 & 0.15 & 46 & Blank & Early & Semi-rosette \\
\hline Polygala spp. & Polygalaceae & 27 & 0.09 & 8 & 2 & Early & \\
\hline Rhinanthus spp. & Orobanchaceae & 24 & 0.36 & 7 & 2 & Late & \\
\hline Luzula multiflora/pallescens/sudetica & Juncaceae & 23 & 0.18 & 7 & 3 & Early & Semi-rosette \\
\hline \multicolumn{8}{|c|}{ Additional species recorded in the plots } \\
\hline Cardamine pratensis & Brassicaceae & 20 & & & & & \\
\hline Solidago virgaurea* & Asteraceae & 13 & & & & & \\
\hline Plantago media & Plantaginaceae & 10 & & & & & \\
\hline Triglochin maritimum & Juncaginaceae & 10 & & & & & \\
\hline Trollius europaeus & Ranunculaceae & 10 & & & & & \\
\hline Euphrasia spp. & Orobanchaceae & 9 & & & & & \\
\hline Lychnis flos-cuculi & Caryophyllaceae & 9 & & & & & \\
\hline Polygonum viviparum & Polygonaceae & 7 & & & & & \\
\hline Armeria maritima & Plumbaginaceae & 6 & & & & & \\
\hline Antennaria dioica & Asteraceae & 5 & & & & & \\
\hline Helianthemum nummularium & Cistaceae & 5 & & & & & \\
\hline Leontodon hispidus & Asteraceae & 5 & & & & & \\
\hline Triglochin palustre & Juncaginaceae & 5 & & & & & \\
\hline Arnica montana & Asteraceae & 4 & & & & & \\
\hline
\end{tabular}


Table 2 continued

\begin{tabular}{|c|c|c|c|c|c|c|}
\hline $\begin{array}{l}\text { Species subjected to individual } \\
\text { analyses }\end{array}$ & $\begin{array}{l}\text { Frequency } \\
\text { in plots } \\
(N=919)\end{array}$ & $\begin{array}{l}\text { Plant } \\
\text { height } \\
\text { (m) }\end{array}$ & $\begin{array}{l}\text { Ellenberg } \\
\text { (L) }\end{array}$ & $\begin{array}{l}\text { Ellenberg } \\
(\mathrm{N})\end{array}$ & $\begin{array}{l}\text { Flowering } \\
\text { time }\end{array}$ & $\begin{array}{l}\text { Leaf } \\
\text { arrangement }\end{array}$ \\
\hline
\end{tabular}

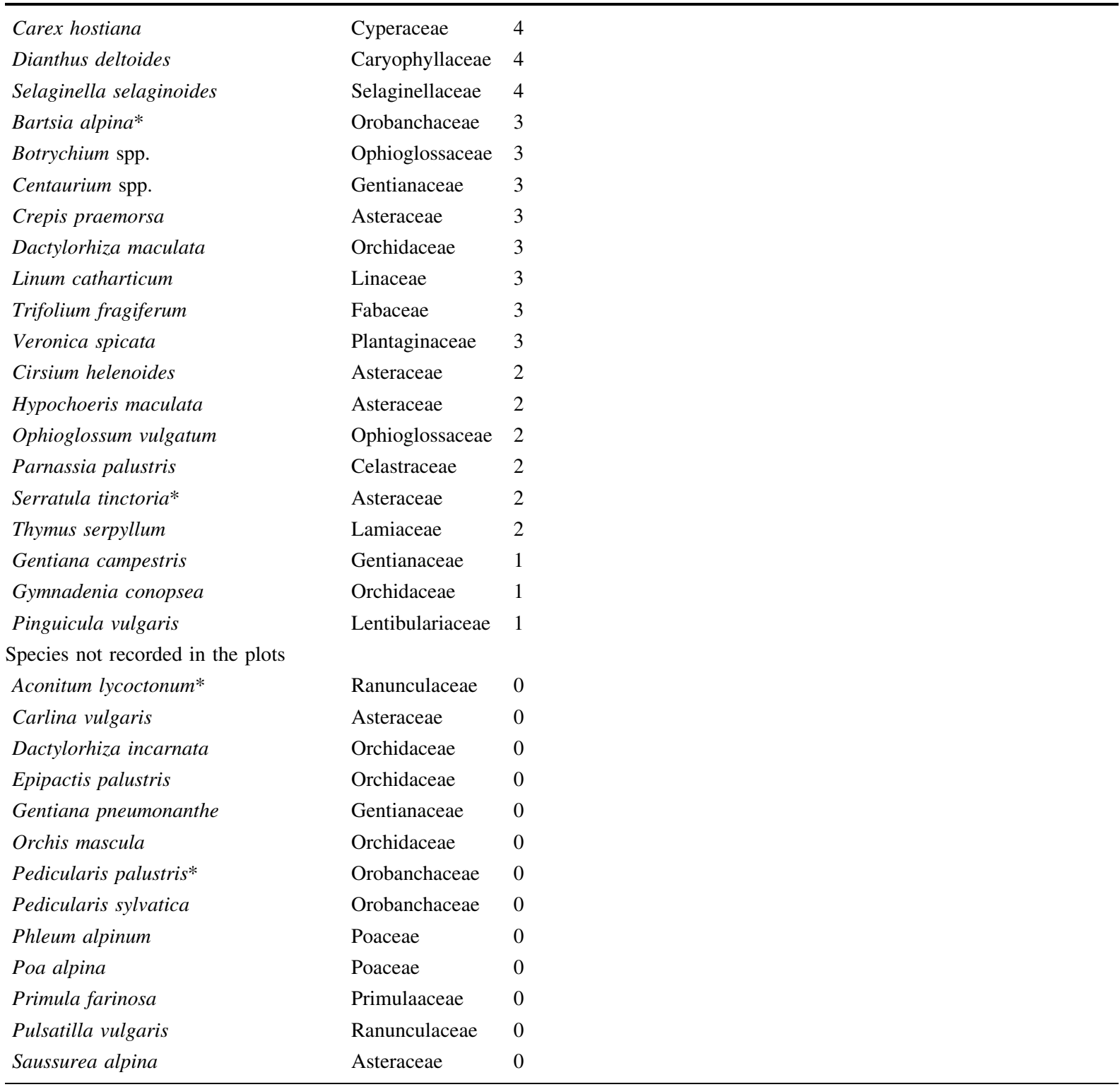

For the species subjected to detailed analyses, five species trats used are reported

*Denotes species not included in the original indicator list (Persson 2005b; Öster et al. 2008), but added to the extended list in the inventory to increase the ecological range for e.g. forest-dominated regions and northern Sweden

\section{References}

Beaufoy G, Jones G, Kazakova Y, McGurn P, Poux X, Stefanova V (2011) Permanent pastures and meadows under the CAP: the situation in 6 countries. European forum on nature conservation and pastoralism. https://www.efncp.
org/download/EFNCP_Permanent-Pastures-and-Meadows. pdf

Bergman KO, Askling J, Ekberg O, Ignell H, Wahlman H, Milberg P (2004) Landscape effects on butterfly assemblages in an agricultural region. Ecography 27:619-628 
Bergstedt J, Milberg P (2001) The impact of logging intensity on field-layer vegetation in Swedish boreal forests. For Ecol Manage 154:105-115

Bertke E, Klimek S, Wittig B (2008) Developing result-orientated payment schemes for environmental services in grasslands: Results from two case studies in North-western Germany. Biodiversity 9:91-95

Blom S, ed. (2012) Hur påverkas natur-och kulturvärden av en striktare betesmarksdefinition? Jordbruksverket 2012:20, $96 \mathrm{pp}$

Carroll T, Gillingham PK, Stafford R, Bullock JM, Diaz A (2018) Improving estimates of environmental change using multilevel regression models of Ellenberg indicator values. Ecol Evol 8:9739-9750

da Silveira PL, Maire V, Schellberg J, Louault F (2015) Grass strategies and grassland community responses to environmental drivers: a review. Agron Sustain Dev 35:1297-1318

Deák B, Tölgyesi C, Kelemen A, Bátori Z, Gallé R, Bragina TM, Yerkin AI, Valkó O (2017) The effects of micro-habitats and grazing intensity on the vegetation of burial mounds in the Kazakh steppes. Plant Ecol Divers 10:509-520

Díaz S, Lavorel S, McIntyre S, Falczuk V, Casanoves F, Milchunas DG, Skarpe C, Rusch G, Sternberg M (2007) Plant responses to grazing: a global synthesis. Global Change Biol 13:313-341

Diekmann M (2003) Species indicator values as an important tool in applied plant ecology: a review. Basic Appl Ecol 4:493-506

Dorrough JW, Ash JE, Bruce S, McIntyre S (2007) From plant neighbourhood to landscape scales: how grazing modifies native and exotic plant species richness in grassland. Plant Ecol 191:185-198

Dover JW, Sparks TH, Greatorex-Davies JN (1997) The importance of shelter for butterflies in open landscapes. J Insect Conserv 1:89-97

Dray S, Legendre P, Peres-Neto PR (2006) Spatial modelling: a comprehensive framework for principal coordinate analysis of neighbour matrices (PCNM). Ecol Modell 196:483-493

Earle DF, McGowan AA (1979) Evaluation and calibration of an automated rising plate meter for estimating dry matter yield of pasture. Aust J Exper Agric 19:337-343

Einarsson A, Milberg P (1999) Species richness and distribution in relation to light in wooded meadows and pastures in southern Sweden. Ann Bot Fennici 36:99-107

Ellenberg H (1991) Zeigerwerte von Pflanzen in Mitteleuropa. Scr Geobot 18:1-248

Eriksson O, Cousins SAO (2014) Historical landscape perspectives on grasslands in Sweden and the Baltic region. Land 3:300-321

Eriksson O, Cousins SA, Bruun HH (2002) Land-use history and fragmentation of traditionally managed grasslands in Scandinavia. J Veg Sci 13:743-748

Evju M, Austrheim G, Halvorsen R, Mysterud A (2009) Grazing responses in herbs in relation to herbivore selectivity and plant traits in an alpine ecosystem. Oecologia 161:77-85

Fujita N, Koda R (2015) Capitulum and rosette leaf avoidance from grazing by large herbivores in Taraxacum. Ecol Res 30:517-525
Gahoonia TS, Raza S, Nielsen NE (1994) Phosphorus depletion in the rhizosphere as influenced by soil moisture. Plant Soil 159:213-218

Gazol A, Tamme R, Takkis K, Kasari L, Saar L, Helm A, Pärtel M (2012) Landscape- and small-scale determinants of grassland species diversity: direct and indirect influences. Ecography 35:944-951

Gilhaus K, Vogt V, Hölzel N (2015) Restoration of sand grasslands by topsoil removal and self-greening. Appl Veg Sci 18:661-673

Gilhaus K, Boch S, Fischer M, Hölzel N, Kleinebecker T, Prati D, Rupprecht D, Schmitt B, Klaus VH (2017) Grassland management in Germany: effects on plant diversity and vegetation composition. Tuexenia 37:379-397

Graham MH (2003) Confronting multicollinearity in ecological multiple regression. Ecology 84:2809-2815

Grandin U, Lenoir L, Glimskär A (2013) Are restricted species checklists or ant communities useful for assessing plant community composition and biodiversity in grazed pastures? Biodiv Conserv 22:1415-1434

Hansson M, Fogelfors H (2000) Management of a semi-natural grassland; results from a 15-year-old experiment in southern Sweden. J Veg Sci 11:31-38

Herrero-Jáuregui C, Oesterheld M (2018) Effects of grazing intensity on plant richness and diversity: a meta-analysis. Oikos 127:757-766

Herzon I, Birge T, Allen B, Povellato A, Vanni F, Hart K, Radleyd G, Tucker G, Keenleyside C, Oppermann R, Underwood E, Poux X, Beaufoy G, Pražan J (2018) Time to look for evidence: Results-based approach to biodiversity conservation on farmland in Europe. Land Use Policy 71:347-354

Humbert J-Y, Dwyer JM, Andrey A, Arlettaz R (2016) Impacts of nitrogen addition on plant biodiversity in mountain grasslands depend on dose, application duration and climate: a systematic review. Global Change Biol 22:110-120

Kelemen A, Török P, Valkó O, Miglécz T, Tóthmérész B (2013) Mechanisms shaping plant biomass and species richness: plant strategies and litter effect in alkali and loess grasslands. J Veg Sci 24:1195-1203

Kleyer M, Bekker RM, Knevel IC, Bakker JP, Thompson K, Sonnenschein M, Poschlod P, Van Groenendael JM, Klimeš L, Klimešová J et al (2008) The LEDA Traitbase: a database of life-history traits of the Northwest European flora. J Ecol 96:1266-1274

Klimek S, Richter-Kemmermann A, Hofmann M, Isselstein J (2007) Plant species richness and composition in managed grasslands: the relative importance of field management and environmental factors. Biol Conserv 134:559-570

Köhler B, Gigon A, Edwards PJ, Krüsi B, Langenauer R, Lüscher A, Ryser P (2005) Changes in the species composition and conservation value of limestone grasslands in Northern Switzerland after 22 years of contrasting managements. Perspect Plant Ecol Evol Syst 7:51-67

Komac B, Domènech M, Fanlo R (2014) Effects of grazing on plant species diversity and pasture quality in subalpine grasslands in the eastern Pyrenees (Andorra): Implications for conservation. J Nat Conserv 22:247-255

Krok T, Almquist S (2012) Svensk flora, 29th edn. Stockholm, Liber AB 
Laca EA, Demment MW, Winckel J, Kie JG (1989) Comparisons of weight estimate and rising-plate meter methods to measure herbage mass of a mountain meadow. J Range Manage 42:71-75

Lennartsson T (2000) Management and population viability of the pasture plant Gentianella campestris: the role of interactions between habitat factors. Ecol Bull 48:111-121

Lennartsson T, Oostermeijer JGB (2001) Demographic variation and population viability in Gentianella campestris: effects of grassland management and environmental stochasticity. J Ecol 89:451-463

Lindborg R, Bengtsson J, Berg $\AA$, Cousins S, Eriksson O, Gustafsson T, Hasund K P, Lenoir L, Pihlgren A, Sjödin E, Stenseke M (2006) Naturbetesmarker i landskapsperspektiv - en analys av kvaliteter och värden på landskapsnivå. CBM:s skriftserie 12. Centrum för biologisk mångfald, Uppsala

Loydi A, Eckstein RL, Otte A, Donath TW (2013) Effects of litter on seedling establishment in natural and semi natural grasslands: a meta-analysis. J Ecol 101:454-464

Meiners SJ, Pickett STA, Cadenasso ML (2015) An integrative approach to successional dynamics: tempo and mode in vegetation change. Cambridge University Press, Cambridge, $\mathrm{p} 303$

Menard C, Duncan P, Fleurance G, Georges J-Y, Lila M (2002) Comparative foraging and nutrition of horses and cattle in European wetlands. J Appl Ecol 39:120-133

Milberg P, Bergman K-O, Cronvall E, Eriksson ÅI, Glimskär A, Islamovic A, Jonason D, Löfqvist Z, Westerberg L (2016) Flower abundance and vegetation height as predictors for nectar-feeding insect occurrence in Swedish semi-natural grasslands. Agric Ecosyst Environ 230:47-54

Milberg P, Tälle M, Fogelfors H, Westerberg L (2017) The biodiversity cost of reducing management intensity in species-rich grasslands: Mowing annually vs. every third year. Basic Appl Ecol 22:61-74

Milberg P, Fogelfors H, Westerberg L, Tälle M (2018) Annual burning of semi-natural grasslands for conservation: winners and losers among plant species. Nordic J Bot NJB 36:01709

Milchunas DG, Sala OE, Lauenroth WK (1988) A generalized model of the effects of grazing by large herbivores on grassland community structure. Am Nat 132:87-106

Misra A, Tyler G (2000) Effects of soil moisture on soil solution chemistry, biomass production, and shoot nutrients in two native grasses on a calcareous soil. Commun Soil Sci Plant Anal 31:2727-2738

Moeslund JE, Arge L, Bøcher PK, Dalgaard T, Ejrnæs R, Odgaard MV, Svenning JC (2013) Topographically controlled soil moisture drives plant diversity patterns within grasslands. Biodivers Conserv 22:2151-2166

Nordberg A (2013) Utvärdering av ängs- och betesmarksinventeringen och databasen TUVA. Hur används TUVA och hur stort är behovet av ominventering? [Evaluation on the National survey of semi-natural pastures and meadows and the database TUVA. How TUVA is utilized and how big the need of a resurvey is?] Jordbruksverket Rapport 2013, 32

Öckinger E, Eriksson AK, Smith HG (2006) Effects of grassland abandonment, restoration and management on butterflies and vascular plants. Biol Conserv 133:291-300
Oelmann Y, Broll G, Hölzel N, Kleinebecker T, Vogel A, Schwartze P (2009) Nutrient impoverishment and limitation of productivity after 20 years of conservation management in wet grasslands of north-western Germany. Biol Conserv 142:2941-2948

Öster M, Persson K, Eriksson O (2008) Validation of plant diversity indicators in semi-natural grasslands. Agric Ecosyst Environ 125:65-72

Pärtel M, Bruun HH, Sammul M (2005) Biodiversity in temperate European grasslands: origin and conservation. In: R Lillak, R Viiralt, A Linke, V Geherman (eds) Integrating Efficient Grassland Farming and Biodiversity. Grassland Science in Europe 10:1-14

Pelve M (2010) Cattle grazing on semi-natural pastures - animal behaviour and nutrition, vegetation characteristics and environmental aspects. Licentiate Thesis. Report 276, Dept of Animal Nutrition and Management, Swedish University of Agricultural Sciences, Uppsala.

Persson K (2005a) Ängs- och betesmarksinventeringen 2002-2004 [Survey of semi-natural pastures and meadows 2002-2004]. Board of Agriculture, Jönköping (In Swedish with English summary)

Persson K (2005b) Ängs- och betesmarksinventeringen: inventeringsmetod [Survey of semi-natural pastures and meadows: methodology. Board of Agriculture, Jönköping

Pihlgren A, Lennartsson T (2008) Shrub effects on herbs and grasses in semi-natural grasslands: positive, negative or neutral relationships? Grass Forage Sci 63:9-21

Plieninger T, Hartel T, Martín-López B, Beaufoy G, Bergmeier E, Kirby K, Montero MJ, Moreno G, Oteros-Rozas E, Van Uytvanck J (2015) Wood-pastures of Europe: geographic coverage, social-ecological values, conservation management, and policy implications. Biol Conserv 190:70-79

Poschlod P, Baumann A, Karlik P (2009) Origin and development of grasslands in central Europe. In: Veen P, Jeffersson R, de Smidt J, van der Straaten J (eds) Grasslands in Europe of high nature value. KNNV Publishing, Zeist, pp 15-25

Pöyry J, Luoto M, Paukkunen J, Pykälä J, Raatikainen K, Kuussaari M (2006) Different responses of plants and herbivore insects to a gradient of vegetation height: an indicator of the vertebrate grazing intensity and successional age. Oikos 115:401-412

Pykälä J (2003) Effects of restoration with cattle grazing on plant species composition and richness of semi-natural grasslands. Biodivers Conserv 12:2211-2226

Pykälä J (2004) Cattle grazing increases plant species richness of most species trait groups in mesic semi-natural grasslands. Plant Ecol 175:217-222

Rook AJ, Dumont B, Isselstein J, Osoro K, WallisDeVries MF, Parente G, Mills J (2004) Matching type of livestock to desired biodiversity outcomes in pastures: a review. Biol Conserv 119:137-150

Rosén E (1982). Vegetation development and sheep grazing in limestone grasslands of south Öland, Sweden. Acta Phytogeogr Suec 72. Uppsala

Schrautzer J, Breuerb V, Holsten B, Jensen K, Rasran L (2016) Long-term effects of large-scale grazing on the vegetation of a rewetted river valley. Agric Ecosyst Environ 216:207-215 
Schrautzer J, Jensen K (2004) Relationship between light availability and species richness during fen grassland succession. Nordic J Bot 24:341-353

Schreiber K-F, Brauckmann H-J, Broll G, Krebs S, Poschlod P (2009) Artenreiches Grünland in der Kulturlandschaft. 35 Jahre Offenhaltungsversuche Baden-Württemberg.Verlag Regionalkultur (in German).

Scohier A, Ouin A, Farruggia A, Dumont B (2013) Is there a benefit of excluding sheep from pastures at flowering peak on flower-visiting insenct diversity? J Insect Conserv 17:287-294

Sjödin M (ed.) (2015). Fältinstruktion för Nationell Inventering av Landskapet i Sverige, NILS och Ä\&B, År 2015. Dept of Forest Resource Management, Swedish University of Agricultural Sciences, Umeå

Söderström BO, Svensson B, Vessby K, Glimskär A (2001) Plants, insects and birds in semi-natural pastures in relation to local habitat and landscape factors. Biodivers Conserv 10:1839-1863

Ståhl G, Allard A, Esseen PA, Glimskär A, Ringvall A, Svensson J, Sundquist S, Christensen P, Torell AG, Högström M, Lagerqvist K, Marklund L, Nilsson B, Inghe O (2011) National Inventory of Landscapes in Sweden (NILS): scope, design, and experiences from establishing a multiscale biodiversity monitoring system. Environ Monit Assess 173:579-595

Stewart GB, Pullin AS (2008) The relative importance of grazing stock type and grazing intensity for conservation of mesotrophic 'old meadow' pasture. J Nat Conserv 16:175-185

Svensson BM, Carlsson BÅ (2005) How can we protect rare hemiparasitic plants? Early-flowering taxa of Euphrasia and Rhinanthus on the Baltic island of Gotland. Folia Geobot 40:261-272

Tälle M, Bergman K-O, Paltto H, Pihlgren A, Svensson R, Westerberg L, Wissman J, Milberg P (2014) Mowing for biodiversity: knife mower and grass trimmer perform equally well. Biodiv Conserv 23:3073-3089
Tälle M, Fogelfors H, Westerberg L, Milberg P (2015) The conservation benefit of mowing vs. grazing for management of species-rich grasslands: a multi-site, multi-year field experiment. Nordic J Bot 33:761-768

Tälle M, Deák B, Poschlod P, Valkó O, Westerberg L, Milberg P (2016) Grazing vs. mowing: a meta-analysis of biodiversity benefits for semi-natural grassland management. Agric Ecosyst Environ 222:200-212

Tälle M, Deák B, Poschlod P, Valkó O, Westerberg L, Milberg P (2018) Similar effects of different mowing frequencies on the conservation value of semi-natural grasslands in Europe. Biodiv Conserv 27:2451-2475

Tóth E, Deák B, Valkó O, Kelemen A, Miglécz T, Tóthmérész B, Török P (2018) Livestock type is more crucial than grazing intensity: traditional cattle and sheep grazing in short-grass steppes. Land Degrad Dev 29:231-239

van Klink R, Nolte S, Mandema FS, Lagendijk DDG, WallisDeVries MF, Bakker JP, Esselink P, Smit C (2016) Effects of grazing management on biodiversity across trophic levels: the importance of livestock species and stocking density in salt marshes. Agric Ecosyst Environ 235:329-339

Wahlman H, Milberg P (2002) Management of semi-natural grassland vegetation: evaluation of a long-term experiment in southern Sweden. Ann Bot Fenn 39:159-166

Wallin L, Svensson BM (2012) Reinforced traditional management is needed to save a declining meadow species. A demographic analysis. Folia Geobot 47:231-247

Wittig B, Richter-Kemmermann A, Zacharias D (2006) An indicator species approach for result-orientated subsidies of ecological services in grasslands: A study in Northwestern Germany. Biol Conserv 133:186-197

Publisher's Note Springer Nature remains neutral with regard to jurisdictional claims in published maps and institutional affiliations. 